\title{
Boosting the suppressive effects of Ascaris suum components in IFN- $\gamma$-deficient mice
}

\author{
Potencialização do efeito supressor de componentes do \\ Ascaris suum em camundongos deficientes em IFN- $\gamma$
}

Valdênia Maria Oliveira Souza ${ }^{1}$ and Mahasti Sahihi Macedo ${ }^{2}$

\begin{abstract}
High molecular weight components from Ascaris suum extract suppress ovalbumin-specific immunity in mice. In IFN- $\gamma$-deficient mice, ovalbuminspecific delayed-type hypersensitivity reactions are more strongly downregulated by these suppressive components. Here, the cellularity of the delayed-type hypersensitivity reaction in IFN- $\gamma$-deficient mice and the increased downregulation induced by Ascaris suum components were analyzed. IL-12p40-dependent neutrophilic influx was predominant. Suboptimal doses of the suppressive fraction from this nematode completely inhibited the hypersensitivity reaction, thus indicating intensification of the immunosuppression under conditions of intense recruitment of IFN- $\gamma$-independent neutrophils.
\end{abstract}

Key-words: Ascaris suum. Delayed-type hypersensitivity. Immunosuppression. IFN- $\gamma$-deficient mice. Neutrophil.

\section{RESUMO}

Componentes de alto peso molecular do extrato de Ascaris suum suprimem a imunidade específica à ovalbumina em camundongos. Em camundongos geneticamente deficientes de IFN- $\gamma$ a reação de hipersensibilidade tardia específica para ovalbumina foi mais fortemente prejudicada por estes componentes supressivos. Aqui, a celularidade da reação de hipersensibilidade tardia em camundongos deficientes de IFN- $\gamma$ e 0 incremento na supressão induzida por componentes do Ascaris suum foram analisados. Influxo neutrofílico, dependente de IL-12p40, foi predominante. Dose subótima da fração supressiva do nematódeo inibiu completamente a reação de hipersensibilidade, indicando uma intensificação da imunossupressão em condições de recrutamento intenso de neutrófilos independente de IFN- $\gamma$.

Palavras-chaves: Ascaris suum. Hipersensibilidade tardia. Imunossupressão. Camundongos deficientes em IFN- $\gamma$. Neutrófilos.

Helminth infections inhibit the host's protective Th1-type immune response to non-related pathogenic agents such as virus, parasites and bacterial antigens ${ }^{1411}$. On the other hand, harmful Th1 or Th2 responses leading to autoimmune encephalomyelitis or enteric allergy, respectively, can be also controlled in the presence of helminth antigens ${ }^{315}$. With regard to the nematode Ascaris suum, the regulatory mechanisms induced by its immunosuppressive components have been the focus of our studies for some time. These components correspond to the high molecular weight fraction, eluted in the first peak (PI), after gel filtration chromatography of the adult Ascaris suum body extract ${ }^{5}$. In mice, when PI was combined with ovalbumin (OVA) and adjuvant, both OVA-specific Th1 and Th2 immune responses were found to be impaired (lymphoproliferation, delayed-type

1. Laboratory of Immunopathology Keizo Asami, Department of Pharmaceutical Sciences, Federal University of Pernambuco, Recife, PE, Brazil. 2. Department of Immunology, Institute of Biomedical Sciences, University of São Paulo, São Paulo, SP, Brazil.

Financial support: Fundação de Amparo à Pesquisa do Estado de São Paulo (FAPESP).

Address to: Dra. Valdênia M.O. Souza. Laboratório de Imunopatologia Keizo Asami/ UFPE. Av. Prof. Moraes Rego s/n, Cidade Universitária, 50670-901 Recife, PE, Brazil.

Tel: 5581 2101-2515; Fax: 5581 2126-8485

e-mail: valdenia.souza@ufpe.br

Received in 19/11/2007

Accepted in 14/04/2009 hypersensitivity (DTH) reactions, IgG2a/IgG1/IgE and IL-2/ IFN- $\gamma /$ IL-4/IL-10 production) $)^{5}$. Using IL-4 or IL-10 knockout mice that were immunized in the same way, we demonstrated the essential role of IL-10 in suppressing the OVA-specific Th2 immune response, while IL-10 plus IL- 4 were required for suppressing Th1-related parameters ${ }^{18}$. In IL-12 or IFN- $\gamma$ knockout mice, the PI suppressive ability remained intact. Unexpectedly, OVA-immunized IFN- $\gamma$-deficient mice developed a very intense OVA-specific DTH reaction, that seemed to be more strongly impaired when these mice received $\mathrm{PI}^{18}$. Thus, in the present study, we investigated the type of infiltrating cell in an OVA-specific DTH and analyzed the intensity of the suppressive effect of PI in the absence of IFN- $\gamma$.

For this, C57BL/6 mice that presented targeted disruption of the IFN- $\gamma$ gene (IFN- $\gamma-/-$ ) and wild-type $\mathrm{C} 57 \mathrm{BL} / 6$ mice were subcutaneously immunized with OVA $(200 \mu \mathrm{g}$ of protein/animal; Sigma Chemical Co) or OVA $(200 \mu \mathrm{g}$ of protein/animal) plus PI ( 200 or $50 \mu \mathrm{g}$ of protein/animal), emulsified in complete Freund's adjuvant (Sigma Chemical Co), on the base of the tail $(0.2 \mathrm{ml} /$ animal). PI was obtained after gel filtration chromatography (XK 26/100 column of Sephacryl S-200; Pharmacia, Uppsala, Sweden) on adult Ascaris suum body extract and was concentrated with Centriprep 100 (Amicon, Beverly, MA, USA) ${ }^{5}$. After eight days, the mice were challenged in the hind footpad with $2 \%$ 
aggregated OVA, and the DTH reaction was measured 24 hours later. Histopathological analyses on footpads (stained with Lunas) from animals in each group were compared. The results represent the mean \pm standard error of the mean for 5-7 animals/group. To test the significance between the groups, one-way analysis of variance was used, followed by multiple comparisons using Tukey's method $^{21}$. Statistical significance was set at $\mathrm{p}<0.05$. The results were representative of three experiments.

As expected, the anti-OVA DTH reaction in IFN- $\gamma-/-$ mice was significantly greater than in wild-type mice (Figure 1). The high dose of PI $(200 \mu \mathrm{g})$ completely suppressed DTH in both wild-type and IFN-deficient mice. In contrast, the low dose $(50 \mu \mathrm{g})$ had this same drastic effect only in IFN- $\gamma$-/- mice. In wild-type mice, this dose reduced the reaction to half of that obtained in wild-type mice immunized with OVA alone. Analysis on the cellular infiltrate in the footpads showed predominance of neutrophils in OVA-immunized IFN- $\gamma$-/- mice, with a few eosinophils, in comparison with intense mononuclear cell infiltrate in the OVA-immunized wild-type mice. Ovalbumin plus PI-immunized IFN- $\gamma-/$ - mice presented scarce cellular infiltrate (data not shown).

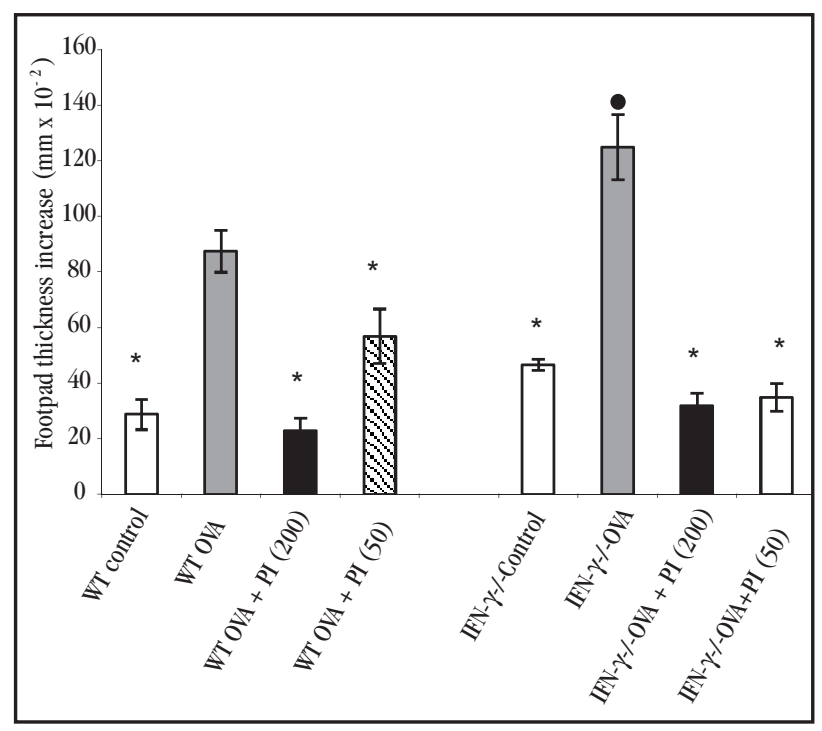

FIGURE 1

Delayed-type hypersensitivity reaction in wild-type or IFN- $\gamma$ knockout (IFN- $\gamma-$-) C57BL/6 mice immunized with ovalbumin or ovalbumin plus Ascaris suum suppressive components, in complete Freund's adjuvant. The reaction was measured 24 hours after challenge with aggregated ovalbumin on the eighth day after immunization. Non-immunized mice (controls) were challenged in the same way. The results represent the mean \pm standard error of the mean for 5-7 animals/group. * $p<0.05$ compared with corresponding ovalbuminimmunized group. $\bullet p<0.05$ compared with ovalbumin-immunized wild-type group.

IL-12 is required for type 1 immune responses and IFN- $\gamma$ production to develop 9 . We have shown that almost no DTH reaction is obtained in our immunization model for genetic deficiency of IL-12 production ${ }^{18}$. Additionally, another IL-12 family member, IL-23, is committed to the Th17-subtype mediated immune response, in which IL-17 is secreted ${ }^{20}$. The Th17-type immune response elicits acute inflammation/neutrophilic respons $^{1420}$. IL-12 and IL-23 share the IL-12p40 subunit, which binds respectively to distinct p35 and p19 subunits, while binding to a specific cell receptor ${ }^{12}$.
Here, we analyzed the role of the IL-12p40 subunit in antiOVA DTH from IFN- $\gamma$-/- mice using an anti-IL-12p40 monoclonal antibody treatment (C17.8; kindly provided by Dr R.L. Coffman, Dynavax Technologies, Berkeley, CA, USA), before immunization with OVA $(200 \mu \mathrm{g}$ of protein/animal) or OVA $(200 \mu \mathrm{g}$ of protein/

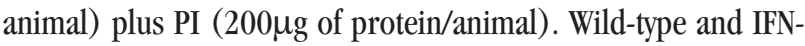
$\gamma$ knockout mice received anti- $\beta$-galactosidase monoclonal control antibody (GL117) before similar immunization. IL-12p40 neutralization eliminated the anti-OVA DTH reaction in the footpad of IFN- $\gamma$-deficient mice (Figure 2), thus corroborating the regulatory function of IL-12 family cytokines in both mononuclear cells and the neutrophilic influx into the footpad after antigen challenge.

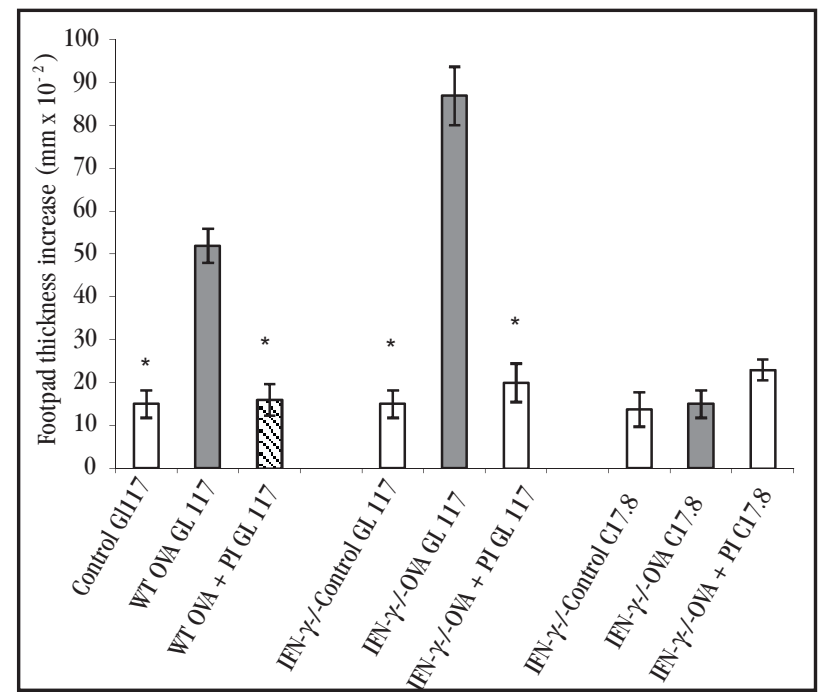

FIGURE 2

Delayed-type hypersensitivity reaction in wild-type or IFN- $\gamma$ knockout (IFN- $\gamma-/-$ ) C57BL/6 mice injected with isotype control anti- $\beta$-galactosidase (GL117) monoclonal antibodies or IFN- $\gamma$ knockout mice injected with anti-IL-12 (C17.8) monoclonal antibodies, before immunization with ovalbumin or ovalbumin plus Ascaris sum suppressive components (OVA+PI), in complete Freund's adjuvant. The reaction was measured 24 hours after challenge with aggregated ovalbumin on the eighth day after immunization. Non-immunized mice (controls) were challenged in the same way. The results represent the mean \pm standard error of the mean for 5-7 animals/group. * $p<0.05$ compared with corresponding ovalbumin-immunized group.

Replacement of a mononuclear cell by eosinophilic or neutrophilic infiltrate due to lack of IFN- $\gamma$ has been demonstrated in experimental infection models ${ }^{2819}$. Here, for OVA immunization, few eosinophils were observed whereas neutrophils were predominant. The pro-inflammatory cytokine TNF- $\alpha$ and neutrophil-attractive chemokines are extensively produced in IFN- $\gamma-/-$ mice $^{28}$ and could become committed to this type of cell influx. Furthermore, the IL-23-IL-17 axis provides synthesis of attractant chemokines and extracellular matrix proteins relating to neutrophil recruitment ${ }^{1420}$.

Induction of IL-10 synthesis by PI has been demonstrated to be the main immunosuppressive mechanism ${ }^{61318}$. It has been shown that PI downregulates the expression of costimulatory agents (CD40, CD80 and CD86) and major histocompatibility complex II molecules on the surface of dendritic cells and, consequently, reduces the antigen-presenting function of these cells. This effect was mediated by IL-10 ${ }^{16}$. IFN- $\gamma$ and IL-10 have opposite effects on 
immune system activation ${ }^{10}$. It is most likely that, in the absence of IFN- $\gamma$, IL-10 induced by PI has a more potent suppressive function, including on TNF- $\alpha$, IL-12 and IL-23 action. This would explain why low doses of PI are more effective in IFN- $\gamma$-deficient mice.

Ascaris species are similar in their capacity to suppress the protective immune response of the host ${ }^{4}$. In this regard, our results show that PI impaired the IL-12p40-mediated neutrophilic influx. IL-23 action has been related to the protective neutrophil response to infection by extracellular bacterial species ${ }^{20}$ or intracellular parasites ${ }^{7}$. On the other hand, Ascaris products have been demonstrated to be a potential therapeutic strategy for inflammatory diseases ${ }^{17}$ such as lung allergic inflammation and LPS-induced inflammation. We hypothesize that PI could fulfill a control strategy for autoimmune inflammation, mediated independently of IL-12-IFN- $\gamma$ (arthritis, multiple sclerosis, psoriasis and inflammatory bowel disease), but strikingly related to IL-23-IL-17 synthesis ${ }^{20}$.

In conclusion, our results indicate that the products from IL-10inducing Ascaris nematodes exhibit improved immunosuppressive properties in settings in which IFN- $\gamma$ synthesis is not essential for the inflammatory process. This finding emphasizes that these molecules have wide use as therapeutic tools for different clinical approaches.

\section{ACKNOWLEDGEMENTS}

We thank by supported by the Research Support Foundation of the State of São Paulo (FAPESP) and Marilú Mazzaro for competent technical assistance.

\section{REFERENCES}

1. Actor JK, Shirai M, Kullberg MC, Buller RM, Sher A, Berzofsky JA. Helminth infection results in decreased virus-specific CD8+ cytotoxic T-cell and Th1 cytokine responses as well as delayed virus clearance. Proceedings of the National Academy of Sciences 90:948-952, 1993.

2. Aliberti JC, Souto JT, Marino AP, Lannes-Vieira J, Teixeira MM, Farber J. Modulation of chemokine production and inflammatory responses in interferon-gamma- and tumor necrosis factor-R1-deficient mice during Trypanosoma cruzi infection. American Journal of Pathology 158:1433-1440, 2001.

3. Bashir ME, Andersen P, Fuss IJ, Shi HN, Nagler-Anderson C. An enteric helminth infection protects against an allergic response to dietary antigen. The Journal of Immunology 169:3284-3292, 2002.

4. Cooper PJ, Chico ME, Sandoval C, Espinel I, Guevara A, Levine MM, Griffin GE, Nutman TB. Human infection with Ascaris lumbricoides is associated with suppression of the interleukin-2 response to recombinant cholera toxin B subunit following vaccination with the live oral cholera vaccine CVD 103-HgR. Infection and Immunity 69:1574-1580, 2001.

5. Faquim-Mauro EL, Macedo MS. The immunosuppressive activity of Ascaris suum is due to high molecular weight components. Clinical and Experimental Immunology 114:245-251, 1998.

6. Itami DM, Oshiro TM, Araújo CA, Perine A, Martins MA, Macedo MS, Macedo-Soares MF. Modulation of murine experimental asthma by Ascaris suum components. Clinical and Experimental Immunology 35:873-879, 2005.

7. Kelly MN, Kolls JK, Happel K, Schwartzman JD, Schwarzenberger P, Combe C, Moretto M, Khan IA. Interleukin-17/interleukin-17 receptor-mediated signaling is important for generation of an optimal polymorphonuclear response against Toxoplasma gondii infection. Infection and Immunity 73:617-621, 2005.

8. Lacroix-Lamande S, Mancassola R, Naciri M, Laurent F. Role of gamma interferon in chemokine expression in the ileum of mice and in a murine intestinal epithelial cell line after Cryptosporidium parvum infection. Infection and Immunity 70:2090-2099, 2002

9. Magram J, Connaughton SE, Warrier RR, Carvajal DM, Wu CY, Ferrante J, Stewart C, Sarmiento U, FahertyDA, Gately MK. IL-12-deficient mice are defective in IFN gamma production and type 1 cytokine responses. Immunity 4:471-478, 1996.

10. Moore KW, Malefyt RW, Coffman RL, O'Garra A. Interleukin-10 and the Interleukin10 Receptor. Annual Review of Immunology 19:683-765, 2001

11. Nacher M, Gay F, Singhasivanon P, Krudsood S, Treeprasertsuk S, Mazier D Vouldoukis I, Looareesuwan S.Ascaris lumbricoides infection is associated with protection from cerebral malaria. Parasite Immunology. 22:107-113, 2000.

12. Oppmann B, Lesley R, Blom B, Timans JC, Xu Y, Hunte B, Vega F, Yu N, Wang J, Singh K, Zonin F, Vaisberg E, Churakova T, Liu M, Gorman D, Wagner J, Zurawski S, Liu Y, Abrams JS, Moore KW, Rennick D, de Waal-Malefyt R, Hannum C, Bazan JF, Kastelein RA. Novel p19 protein engages IL-12p40 to form a cytokine, IL-23, with biological activities similar as well as distinct from IL-12. Immunity 13: $715-725,2000$

13. Oshiro TM, Macedo MS, Macedo-Soares MF. Anti-inflammatory activity of PAS-1, a protein component of Ascaris suum. Inflammation Research 54:17-21, 2005.

14. Reiner SL. Development in motion: helper T cells at work. Cell 129:33-36, 2007 .

15. Sewell D, Qing Z, Reinke E, Elliot D, Weinstock J, Sandor M, Fabry Z. Immunomodulation of experimental autoimmune encephalomyelitis by helminth ova immunization. International Immunology 15:59-69, 2003

16. Silva SR, Jacysyn JF, Macedo MS, Faquim-Mauro EL. Immunosuppressive components of Ascaris suum down-regulate expression of costimulatory molecules and function of antigen-presenting cells via an IL-10-mediated mechanism. European Journal of Immunology 36:3227-3237, 2006.

17. Soares MF, Araújo CA. Helminth products as a potential therapeutic strategy for inflammatory diseases. Inflammation and Allergy Drug Targets 7:113-118, 2008.

18. Souza VM, Jacysyn JF, Macedo MS. IL-4 and IL-10 are essential for immunosuppression induced by high molecular weight proteins from Ascaris suum. Cytokine 28:92-100, 2004.

19. Wang S, Fan Y, Brunham RC, Yang X. IFN-gamma knockout mice show Th2associated delayed-type hypersensitivity and the inflammatory cell fail to localize and control chlamydial infection. European Journal of Immunology 29:37823792, 1999 .

20. Weaver CT, Harrington LE, Mangan PR, Gavrieli M, Murphy KM. Th17: an effector CD4 T cell lineage with regulatory T cell ties. Immunity 24:677-688, 2006.

21. Zar JH. Biostatistical analyses. Printice Hall, New Jersey 1996. 